\author{
STUDIA POLONIJNE \\ T. 42 LUBLIN 2021 \\ DOI: http://doi.org/10.18290/sp2142.9
}

MATEUSZ SZAST

KAROLINA GĄSIOR

\title{
MIGRATION STRATEGIES AND EXPERIENCES OF STUDENTS - BASED ON OWN RESEARCH IN 2020
}

\section{INTRODUCTION}

When referring to migration, the movement of people in order to achieve own aspirations (material, emotional, academic, etc.), it becomes remarkable from the research point of view to gain knowledge of the approach strategies of migrants as participants of migration to their lives and the shaping of life on the basis of leaving or travelling across Polish border. However, due to the limitations of travelling and the impossibility of carrying out field research, as authors we decided to ask academic youth about their opinions on the issue, above all young people assume certain strategies of implementing their own life plans, which may be related to migration experiences or intentions in this area. In this article, the authors will try to answer the question: what are the current preferences of Poles regarding travelling abroad in the opinion of their respondents (students)? We will also attempt to define the very term of migration strategy from the analytical point of view and will try to demonstrate the respondents' strategies in relation to their possible migration experiences or migration intentions.

MATEUSZ SZAST - doctor of social sciences in sociology, master of law, rener of business and Corach, assistant professor at the Institute of Philosophy and Sociology of the Pedagogical University named after the Commission of National Education in Krakow; e-mail: mateusz.szast @up.krakow.pl; ORCID: https://orcid.org/0000-0001-5677-6471.

KAROLINA GĄSIOR - a second year student of sociology at the Institute of Philosophy and Sociology of the Komisja Edukacji Narodowej Pedagogical University in Kraków; e-mail: karolina.gasior2@student.up.krakow.pl. 


\section{CONCEPTUALISATION OF THE MIGRATION STRATEGY APPROACH}

Marek Okólski and Izabela Grabowska-Lusińska within the project "Global migration strategies of Poles hidden in statistical data of receiving countries", on the basis of statistical data of countries receiving Poles after 1 May 2004, presented the following types of migration strategies of compatriots:

1. sectoral strategy as a space for analysis of sectoral allocation of Poles in selected receiving countries and post-accession analysis of changes in these distributions. This strategy established the existence of sectors with pre- and post-accession migration densities, which may also apply to the post-accession migration geography, especially in the UK.

2 . The strategy of delayed spatial dispersion as an analysis of the change or post-accession status quo of concentrations of Poles mainly in the UK, Ireland, Norway and Spain, indicating the spillover from metropolises to their neighbouring areas, up to the periphery in the countries recording the intensity of inflow dynamics (British Isles) and on the relative status quo in countries with established migrant chains (e.g. Norway, Spain, Germany, the Netherlands).

3. The strategy of latent skills depreciation as an analysis of the loss of qualifications of Polish labour migrants in the conditions of labour flows compared to the pre-accession period. This strategy indicates the attracting power of industries with jobs requiring low qualifications, including language skills (which is one of the most important barriers for Poles to take up jobs with formal qualifications), implying the depreciation of migrants' qualifications.

4. The strategy of leaving the hidden economy connects with the previous strategy of depreciation of qualifications, refers to the post-accession phenomenon of the change of the migration status from illegal to legal (removal of restrictions on access to labour markets or obtaining the status of an EU citizen).

5. The strategy of rapacity for job and type of migration by its duration concerns the analysis of the dominant type of migration, namely economic migration in the post-accession migration streams and professional activity of Poles on emigration. Furthermore, this strategy is related to the period of emigration and emphasizes, still essential, seasonal migration, even in the context of the British Isles.

6. The "family" strategy analyses the marital status of Poles in selected destination countries and the structure of households formed by them, since 
post-accession migration is dominated by singles whereas barely $30 \%$ are married $^{1}$.

Monika Gacek analysed migration strategies in Scotland where research led to the conclusion that a longer stay outside the borders of the motherland is tantamount to postponing the return to Poland (27 percent settled permanently). According to the author,

none of the participants of the interviews in Edinburgh expresses a desire to settle there permanently, however, many of them have been there for several years and there is no indication that this situation will change. A large proportion of both groups say that they would prefer to live in Poland and that the factor that keeps them in the UK is the earnings, the opportunity to live in a higher standard of living. Some of them are raising money to buy a flat in Poland, to start a business or to provide financial security in case they return to their home country. Over half of the respondents (52\%) consider themselves to be Polish, while $40 \%$ describe themselves as European and $8 \%$ as global citizens. No respondents describe themselves as British. There is a correlation that migrants who arrived relatively recently consider themselves Poles, but as they stay longer and longer, they begin to feel that they are primarily European citizens ${ }^{2}$.

A different breakdown of the strategy is given by Prof. John Eade, Dr. Stephen Drinkwater and Dr. Michał P. Garapich in the 2006 report entitled "Polish migrants in London - social class and ethnicity" carried out by the CRONEM institute (Centre for Research on Nationalism, Ethnicity and Multiculturalism). They distinguished then 4 groups of migrants: stork, hamster, bushman, salmon ${ }^{3}$. The typology introduced by the mentioned authors is also well developed by Polish researchers. These authors distinguished then the following strategies / types of migrants:

1. The stork type - this is an emigrant who, leaving his family in his home country, decides to emigrate for work in order to raise the standard of living or improve the household budget. He returns to the country to visit

\footnotetext{
${ }^{1}$ M. OKÓLSKI, I. GRABOwSKA-LUSIŃSKA, Najnowsza emigracja z Polski - raport OBM, "Biuletyn Migracyjny" 2008, no. 16, p. 8.

${ }^{2}$ M. GaceK, Strategie migracyjne Polaków po 2004 roku. Przypadek Szkocji, "Pogranicze. Polish Borderlands Studies" 1(2013), no. 1, p. 108.

${ }^{3}$ S. Drinkwater, J. Eade, M.P. GaraPich, Polscy migranci $w$ Londynie - klasa spoleczna i etniczność. Center for Research on Nationalism, Ethnicity and Multiculturalism, University of Surrey. CRONEM 2006, https://www.surrey.ac.uk/cronem/files/RAPORT-finalny.pdf [accessed: 01.01.2016].
} 
and then goes to work abroad again ${ }^{4}$. Stork type is a migrant leaving for a period from 2 months to 6 months, the group of storks include students, seasonal migrants taking up low-paid jobs 5 .

2. The hamster type - a hamster is a person who usually leaves only once for a longer uninterrupted ${ }^{6}$ stay, an emigrant who wants to as soon as possible acquire a certain amount of money sufficient to meet the needs, dreams or aspirations that are the purpose of his earnings - so as to after the implementation of his financial plan return to the country ${ }^{7}$.

3. The bush type - is an emigrant who treats going abroad as an adventure, a passion and does not exclude any option - neither returning, nor settling in another country or going somewhere else. This type has also been called the global teenager type.

4. The classic emigrant - this is a person who leaves in order to find a comfortable place for himself outside Poland, leaving permanently to live outside his home country.

5. The koala bear type - this is a person who does not return to the country of origin due to emigration defeat, i.e. lack of work or inadequate expenses, takes up nomadic lifestyle at railway stations, car parks, shelters.

6. The peasant-worker - despite the fact that sometimes they have a much better profession, they do not lose contact with their family and country of origin because they commute to their place of employment several times a month ${ }^{8}$.

7. The salmon type - represents people who do not want to return to Poland, intending to settle permanently abroad, where they see further, better opportunities than at home ${ }^{9}$.

An interesting research using LSA (Livelihood strategy approach) was conducted by Ann White on a sample of 49 sub-structured interviews with respondents of Polish origin from Limanowa and Grajewo. The author has shown the phenomenon of recurrent migration due to insufficient means of subsistence in their natural living conditions. The mentioned towns were characterised by a significant percentage of unemployed people reaching

\footnotetext{
${ }^{4}$ J. KozIELSKA, Poakcesyjne migracje zarobkowe. Kontekst teoretyczno-empiryczny. Wsparcie społeczne, Poznań 2014, p. 90.

${ }^{5}$ S. KozaK, Patologia eurosieroctwa w Polsce. Skutki migracji zarobkowej dla dzieci i ich rodzin, Warszawa 2010, p. 38.

${ }^{6}$ Tamże, p. 21.

${ }^{7}$ J. KozIELSKA, Poakcesyjne migracje..., p. 90.

${ }^{8}$ Ibidem.

${ }^{9}$ S. Kozak, Patologia ..., p. 38.
} 
even $22 \%$, low wages and lack of real chances to take up a job due to nepotistic restrictions or uncomfortable working conditions (hours) for parents with children, e.g. in large-format shops. Respondents, despite their frequent reluctance, were forced by the situation of their existence (financial obligations, children's education) to migrate in circular migration ${ }^{10}$. A similar approach, a classic formulation of this strategy was included in the work Rural livelihoods and diversity in developing countries, published in Oxford University Press in 2000 by Frank Ellis ${ }^{11}$. The author characterises the complexity of life in rural areas, which in the changing social reality prove to be insufficient for the population to survive, thus forcing them to perform other professions in order to provide for themselves and their families. In the first verses the author defines the concept of life strategy as means to a living and the development and different treatment of this concept (as the author says the sources) come from the situational context adopted by the researcher in which he undertakes his considerations ${ }^{12}$. He expressed strategies as: A livelihood comprises the assets (natural, physical, human, financial, and social capital), the activities, and the access to these (mediated by institutions and social relations) that together determine the living gained by the individual or household. (A livelihood comprises the assets (natural, physical, human, financial, and social capital), the activities, and the access to these (mediated by institutions and social relations) which together define the life gained by an individual or household) ${ }^{13}$.

A different approach is presented by Patrycja Kaniejska, who shows a similar approach, however in her project (which was a doctoral project) she focused on migrant women and their approach to going abroad in order to 'earn' and as well to provide adequate (emotional) conditions for their relatives (cell-phone-moms and dads $)^{14}$ using global chains of care ${ }^{15}$. In addition, Paulina Pustułka discusses women's migration in her article Polish Mothers on the Move: Transnationality and Discourses of Gender, Care, and Co-resi-

\footnotetext{
${ }^{10}$ A. White, Polish circular migration and marginality: a livelihood strategy approach, "Studia Migracyjne - Przegląd Polonijny" 42(2016), no. 1(159), p. 158.

${ }^{11}$ F. ELLIS, Rural livelihoods and diversity in developing countries, Oxford: Oxford University Press 2000, p. 6.

${ }^{12}$ Ibidem, p. 7.

${ }^{13}$ Ibidem, p. 10

${ }^{14} \mathrm{P}$. KNIEJSKA, Between virtual intimacy and the transfer of family members to the workplace. Strategies of migrant care workers to deal with the temporary separation from their families in Poland, "Studia Migracyjne - Przegląd Polonijny" 41(2015), no. 3(157), p. 123.

${ }^{15}$ J. Fudge, Global Care Chains: Transnational Migrant Care Workers, http://www.ialsnet. org/meetings/labour/papers/FudgeCanada.pdf [accessed: 12.12.2011].
} 
dentiality Requirement in the Narratives of Polish Women Raising Children in the West, where the author defines migration strategies of contemporary women through the prism of their family experiences and dilemmas ${ }^{16}$.

The issue of strategies in the context of migration to Ireland was additionally raised by Łukasz Klimek in his article, however, he based his research on the strategy of integration and acculturation of Poles in the multiethnic society of Ireland, which became an immigrant country at the beginning of the 20th century. The author distinguished 4 approaches (strategies), which he then discussed: integration, acculturation, separation and marginalization ${ }^{17}$. The research results showed that the dominant strategies among Poles were integration and separation, taking into account the behavioural approach, the author concluded that "separation behaviours were the most common. The second most popular were integration behaviours. These results are in contrast with regard to adaptation preferences, where the inclination towards the integration strategy dominated over the separation strategy"18. What is more noteworthy, is the analysis of migration theories, especially Everett Lee's approach - Push and Pull with particular reference to, as well as pull and push factors, intervening obstacles, i.e. indirect, frictional (friction factors) which include: cultural-mental differences, unfamiliarity with foreign languages, distance and high costs of movement ${ }^{19}$ which remain significant in the implementation of a migration plan ${ }^{20}$.

For the purposes of this project we adopted an operational definition of the migration strategy as a specific plan of human action in the area of the decision to go abroad, as well as a way to implement this plan. Nowadays, a person undertaking migration uses migration chains, migration networks based on strong ties built within the area of the ethnic group of originhence the regionalisation of migrants (noticeable diasporas of Polish migrants from specific regions in different countries, e.g. Nowy Sacz, Monki, Radgoszcz, where Poles travelled mainly to the United States. It was assumed that a contemporary young person (student) as a result of individualisation of

${ }^{16}$ P. PustuŁka, Polish Mothers on the Move: Transnationality and Discourses of Gender, Care, and Co-residentiality Requirement in the Narratives of Polish Women Raising Children in the West, "Studia Sociologica" 4(2012), vol. 2, p. 165.

${ }^{17}$ Ł. KLIMEK, Polscy migranci mieszkajacy w Irlandii ich strategie akulturacyjne i stosunek wobec integracji, "Studia Migracyjne - Przegląd Polonijny” 38(2012), no. 3, p. 28.

${ }^{18}$ Ibidem, p. 49.

${ }^{19}$ E. LEE, A Theory of migration, "Demography" 1966, vol. 3, p. 16.

${ }^{20}$ A. Richmond, Immigration and Structural Change: The Canadian Experience 1992, 1971 1986, "International Migration Review” 1992, vol. 26, no. 4, p. 1211. 
life, as well as growing up in a consumer global society, equipped with language communication skills, furthermore technical capabilities in terms of crossing borders, communicating at a distance, dealing with issues related to eating out, is in this respect more independent than a person two decades ago. In addition, we have not excluded the use of family experience along with the usual possibilities of implementing the migration plan through migration chains or family migration (family reunification). Personal reasons are further an important element of departure, e.g. dissatisfaction with the political and economic system, or to put it simply, the social climate prevailing in Poland, which, in a way, may influence the decision to leave based on a cool calculation of costs and losses incurred in such an undertaking.

\section{RESEARCH APPROACH DURING PROJECT IMPLEMENTATION}

In order to gather research material concerning the respondents' opinions on migration, their migration experiences or preferences regarding leaving Poland. Due to the inability to carry out field research - a safe form of research, which does not burden the respondents as well as the respondent during direct contact - it became the execution of research via the Internet CAWI. The conducted research did not satisfy the demands of representative research (we did not perform additional statistics), which does not mean that the obtained results do not shed any light on the understanding of trust or distrust among young people. The material is the outcome of research conducted by the Interdisciplinary Scientific Circle "Apertum" among a surveyed population of 820 people aged 18-26. The aim was to recognize the respondents' opinions on migration, their experiences of migration, their preferences with regard to life strategies, as well as possible migration strategies they are able to acquire in their lives. The research material was collected from 811 people within 2 weeks. Only closed questions were asked. The research lasted from 28 December 2020 to 10 January 2021. 820 questionnaires were collected, respondents were recruited through emails asking them to complete the questionnaire, instant messaging was applied as well (Messenger, Tweeter, web chats, Facebook, student mail or MS Teams platform). In the course of the research, no random sampling was applied, the research is not representative, therefore its results will not be generalised to the entire community of young people aged 18-25 in Poland. 
The starting motive for raising the issue of migration or migration preferences of young people in times of epidemics is the desire to learn about their opinions, knowledge, experiences and life strategies, which are significantly influenced by the time in which the contemporary youth lives.

Metrics

Table 1. Gender of respondents $(\mathrm{N}=808)$

\begin{tabular}{|l|c|c|}
\hline Gender & Female & Male \\
\hline Number of respondents (N) & 525 & 283 \\
\hline Percentage of respondents (\%) & $65 \%$ & $35 \%$ \\
\hline
\end{tabular}

Source: Own calculations

Considering the research sample, more than half of the respondents are women $(65 \%)$. On the other hand, men are $35 \%$ of the total number of respondents.

Table 2. Age of people participating in the survey $(\mathrm{N}=803)$

\begin{tabular}{|c|c|c|c|c|c|c|c|c|}
\hline & $\mathbf{1 9}$ & $\mathbf{2 0}$ & $\mathbf{2 1}$ & $\mathbf{2 2}$ & $\mathbf{2 3}$ & $\mathbf{2 4}$ & $\mathbf{2 5}$ & Total \\
\hline $\begin{array}{c}\text { Number of } \\
\text { respondents } \\
(\mathbf{N})\end{array}$ & 103 & 126 & 113 & 101 & 136 & 111 & 113 & 803 \\
\hline $\begin{array}{c}\text { Percentage of } \\
\text { respondents } \\
\mathbf{( \% )}\end{array}$ & $\begin{array}{c}12,8 \\
\%\end{array}$ & $\begin{array}{c}15,7 \\
\%\end{array}$ & $\begin{array}{c}14,1 \\
\%\end{array}$ & $\begin{array}{c}12,6 \\
\%\end{array}$ & $\begin{array}{c}16,9 \\
\%\end{array}$ & $\begin{array}{c}13,8 \\
\%\end{array}$ & $\begin{array}{c}14,1 \\
\%\end{array}$ & $100 \%$ \\
\hline
\end{tabular}

Source: Own calculations

Young people aged 19-25 took part in the research. The largest group were people aged $23(16.9 \%)$, and the smallest group were young people aged $22(12.6 \%)$. It is worth emphasising that the number of respondents in a given age group was comparable. 
Table 3. Place of origin of people participating in the survey $(\mathrm{N}=810)$

\begin{tabular}{|l|c|c|}
\hline Place of residence & $\begin{array}{l}\text { Number of } \\
\text { respondents (N) }\end{array}$ & $\begin{array}{l}\text { Percentage of } \\
\text { respondents (\%) }\end{array}$ \\
\hline Rural areas & 273 & $33,7 \%$ \\
\hline $\begin{array}{l}\text { City with up to 20 thousand } \\
\text { inhabitants }\end{array}$ & 124 & $15,3 \%$ \\
\hline $\begin{array}{l}\text { City to 100 thousand } \\
\text { inhabitants }\end{array}$ & 124 & $15,3 \%$ \\
\hline City to 500 thousand inhabitants & 117 & $14,4 \%$ \\
\hline $\begin{array}{l}\text { City with more than 500 } \\
\text { thousand inhabitants }\end{array}$ & 172 & $21,2 \%$ \\
\hline Total & 810 & $100 \%$ \\
\hline
\end{tabular}

Source: Own calculations

Most of the surveyed young people live in rural areas $-33.7 \%$ of the respondents. Furthermore, the respondents come from cities with over 500 thousand inhabitants $(21.2 \%)$, up to 100 thousand inhabitants $(15.3 \%)$, up to 20 thousand inhabitants (15.3\%) and 500 thousand inhabitants $(14.4 \%)$.

\section{ANALYSIS OF THE COLLECTED RESEARCH MATERIAL REGARDING THE RESPONDENTS' OPINIONS ON MIGRATION AND MIGRATION STRATEGIES}

The primary question asked to the group of respondents concerned the potential reasons which, in the opinion of the interviewed, induce Poles to travel to a foreign country. According to the vast majority, the main factor motivating Poles to migrate is too low income. This opinion is shared by $74.8 \%$ of all respondents. An equally encouraging reason for leaving Poland, according to $44.1 \%$ of respondents, is the possibility to earn money quickly, which will enable the realisation of important plans in the home country. Lack of security and political freedom is the main source of going abroad according to $30.6 \%$ of respondents (tab. 4 ). 
Table 4. Motives of Poles for going abroad $(\mathrm{N}=813)$

\begin{tabular}{|l|c|c|}
\hline & $\begin{array}{c}\text { Number of } \\
\text { respondents (N) }\end{array}$ & $\begin{array}{c}\text { Percentage } \\
\text { of } \\
\text { respondents } \\
\text { (\%) }\end{array}$ \\
\hline Unemployment & 193 & $23,7 \%$ \\
\hline Underpaid & 608 & $74,8 \%$ \\
\hline $\begin{array}{l}\text { Perspective of working on "junk contracts" } \\
\text { in Poland }\end{array}$ & 120 & $14,8 \%$ \\
\hline $\begin{array}{l}\text { Lack of prospects for professional development } \\
\text { in the country of origin }\end{array}$ & 244 & $30 \%$ \\
\hline $\begin{array}{l}\text { Lack of sense of security and political freedom } \\
\text { in the country }\end{array}$ & 249 & $30,6 \%$ \\
\hline Sense of discrimination & 143 & $17,6 \%$ \\
\hline $\begin{array}{l}\text { Willingness to meet new places, people and } \\
\text { change the environment }\end{array}$ & 215 & $26,4 \%$ \\
\hline $\begin{array}{l}\text { Willingness to earn fast money to realize } \\
\text { important plans in the country }\end{array}$ & 334 & $41,1 \%$ \\
\hline Other & 10 & $1,2 \%$ \\
\hline Total & 813 & $100 \%$ \\
\hline
\end{tabular}

Source: Own calculations

It may be assumed that the current political and economic situation deepens fears among the surveyed youth and they more often consider leaving. Slightly less, i.e. $30 \%$ of respondents believe that the lack of perspectives for professional development is a factor significantly influencing the decision to emigrate. However, for $26.4 \%$ of respondents the important issue is the will to get to know new places, people and change the environment. However, the others believe that the reasons which mobilise Poles to leave are i.a. unemployment (23.7\%), the feeling of discrimination (17.6\%) or the perspective of working on the so-called junk contract, which results in instability and living in constant fear $(14.8 \%)$. Only $1.2 \%$ of respondents mentioned other factors, such as love, persecution on the grounds of sexual orientation, the ruling party or difficult bureaucracy, especially concerning foreigners. One of the respond- 
ents was so outraged by the current situation in Poland that he explicitly expressed that, in his opinion, the country is full of absurdities and the Polish society should decide to migrate without a second thought.

It should be noted that $3 / 4$ of the respondents focus on such motives as money, getting rich, acquiring more material goods, which may be interpreted as a manifestation of materialism and consumerism. Only a small percentage of respondents focuses on such issues as the desire to get to know new places, people, cultures, gaining knowledge.

Table 5. Circumstances of the decision made by the respondents about $(\mathrm{N}=517)$

\begin{tabular}{|l|c|c|}
\hline & $\begin{array}{c}\text { Number of } \\
\text { respondents } \\
\text { (N) }\end{array}$ & $\begin{array}{c}\text { Percentage } \\
\text { of } \\
\text { respondents } \\
\text { (\%) }\end{array}$ \\
\hline $\begin{array}{l}\text { Individual decision taken without consulting } \\
\text { family and friends }\end{array}$ & 135 & $26,1 \%$ \\
\hline $\begin{array}{l}\text { Decision made together with relatives (partner/ } \\
\text { partner/husband/wife/children/parents etc.) }\end{array}$ & 212 & $41 \%$ \\
\hline $\begin{array}{l}\text { Decision resulting from calculation of living } \\
\text { conditions in Poland and further country from } \\
\text { sources available in the media }\end{array}$ & 126 & $24,4 \%$ \\
\hline $\begin{array}{l}\text { Decision resulting from conversations with friends } \\
\text { and acquaintances who encouraged me to leave }\end{array}$ & 112 & $21,7 \%$ \\
\hline $\begin{array}{l}\text { I do not remember the circumstances of my } \\
\text { decision to leave }\end{array}$ & 69 & $13,3 \%$ \\
\hline Total & 517 & $100 \%$ \\
\hline
\end{tabular}

Source: Own calculations

The second question aimed to establish what were the circumstances of the respondents' decision to travel abroad (respondents with migration experience answered). As admitted by almost half of the respondents (41\%), the decision was taken together with people close to them, such as their partner, spouse or parents. An independent decision, without consulting family or friends was taken by $26.1 \%$ of respondents. Almost $1 / 4$ of the surveyed persons 
admit that they decided to leave thanks to calculating the living conditions in Poland and a different country on the basis of available sources in the media. They stated that the situation abroad is much more conducive to their standard of living. On the other hand, $21.7 \%$ of those interviewed were encouraged to leave by their friends. Only $13,3 \%$ of respondents don't remember what the circumstances were when they decided to leave (tab. 5). Respondents value the opinion of their family, partner or friends and willingly suggest their advice when making important life decisions.

Table 6. Nature of respodents' trip abroad $(\mathrm{N}=510)$

\begin{tabular}{|l|c|c|}
\hline & $\begin{array}{c}\text { Number of } \\
\text { respondents } \\
\text { (N) }\end{array}$ & $\begin{array}{c}\text { Percentage of } \\
\text { respondents } \\
\text { (\%) }\end{array}$ \\
\hline Individual - I went alone & 216 & $42,3 \%$ \\
\hline $\begin{array}{l}\text { First I went alone then I took my family } \\
\text { with me }\end{array}$ & 37 & $7,3 \%$ \\
\hline Trip with entire family & 38 & $7,5 \%$ \\
\hline Trip with a group of friends/acquaintances & 204 & $40 \%$ \\
\hline $\begin{array}{l}\text { I came alone or with my family to another } \\
\text { country after staying in a different country }\end{array}$ & 15 & $2,9 \%$ \\
\hline Total & 510 & $100 \%$ \\
\hline
\end{tabular}

Source: Own calculations

Following the process of gathering information on the respondents' migration experiences, an important aspect was to find out the nature of the trip (tab. 6). A large group of respondents (42.3\%) admits that their trip was of individual character. Not much less, $40 \%$ of the respondents went abroad with a group of friends or acquaintances. Such decision may have been caused by the fact that travelling in the company of close people is much safer than travelling alone, especially when the direction of migration is a completely foreign, unknown country. In the case of $7.5 \%$ of the respondents, the whole family travelled together. On the other hand, for $7.3 \%$ of respondents their trip was individual at first, after which also their family decided to join them. Only $2,9 \%$ of the respondents came alone or with their family to another country after a stay in another country. On this basis, it may be 
concluded that the youth under study do not migrate very frequently - if they do, it is only for a limited period of time and after that they return to Poland or stay in the chosen foreign country permanently.

Table 7. Estimated period of respondents' stay abroad $(\mathrm{N}=514)$

\begin{tabular}{|l|c|c|}
\hline & $\begin{array}{c}\text { Number of } \\
\text { respondents (N) }\end{array}$ & $\begin{array}{c}\text { Percentage of } \\
\text { respondents (\%) }\end{array}$ \\
\hline $\begin{array}{l}\text { I did not assume the length of stay } \\
\text { abroad }\end{array}$ & 261 & $50,8 \%$ \\
\hline Less than a year & 151 & $29,4 \%$ \\
\hline One year & 29 & $5,6 \%$ \\
\hline 2-5 years & 35 & $6,8 \%$ \\
\hline More than 5 years & 11 & $2,1 \%$ \\
\hline Permanent & 27 & $5,3 \%$ \\
\hline Total & 514 & $100 \%$ \\
\hline
\end{tabular}

Source: Own calculations

The following question (tab. 7) concerned the length of the planned stay abroad for people with migration experience. $1 / 2$ of the respondents $(50.8 \%)$ did not specify the exact period of stay abroad before departure. On the other hand, $29.4 \%$ of the respondents knew that their stay abroad would last less than a year. The rest of the respondents expected to stay for $2-5$ years $(6.8 \%)$, one year $(5.6 \%)$ and at least 5 years $(2.1 \%)$. It should be noted that only $5.3 \%$ of the surveyed youth admit that from the very beginning their departure was connected with moving permanently outside Poland. Migrations are rather short-lived and most respondents returned to Poland eventually.

Table 8. Preparations of the surveyed before going abroad $(\mathrm{N}=515)$

\begin{tabular}{|c|c|c|c|}
\hline & Yes & No & Total \\
\hline Number of respondents (N) & 301 & 214 & 515 \\
\hline Percentage of respondents (\%) & $58,4 \%$ & $41,6 \%$ & $100 \%$ \\
\hline
\end{tabular}

Source: Own calculations 
Along with the decision to travel abroad, it is also worth taking into account the appropriate preparation of the respondents for the trip. Moreover, the authors questioned the respondents with regard to this subject. More than half of the respondents $(58.4 \%)$ admitted that yes, they had made adequate preparations before departure, which enabled them to adapt to the new reality more easily. On the other hand, $41.6 \%$ of the respondents did not take any actions or efforts (tab. 8).

Table 9. Types of preparation of respondents before leaving Poland $(\mathrm{N}=306)$

\begin{tabular}{|l|c|c|}
\hline & $\begin{array}{c}\text { Number of } \\
\text { respondents } \\
(\mathbf{N})\end{array}$ & $\begin{array}{c}\text { Percentage of } \\
\text { respondents } \\
\text { (\%) }\end{array}$ \\
\hline Learning English & 112 & $36,6 \%$ \\
\hline $\begin{array}{l}\text { Looping for information in the press and the Internet } \\
\text { about the conditions of staying in another country }\end{array}$ & 152 & $49,7 \%$ \\
\hline $\begin{array}{l}\text { Looping for friends or acquaintances in another } \\
\text { country }\end{array}$ & 77 & $25,2 \%$ \\
\hline Looking for a job abroad through friends or family & 117 & $38,2 \%$ \\
\hline $\begin{array}{l}\text { Looping for a job abroad through a recruitment } \\
\text { agency (agencies) }\end{array}$ & 66 & $21,6 \%$ \\
\hline Other & 11 & $3,6 \%$ \\
\hline Total & 306 & $100 \%$ \\
\hline
\end{tabular}

Source: Own calculations

Almost half of the respondents (49.7\%) looked for information in the press and the Internet about the conditions of their stay abroad in order to prepare themselves adequately for a country so far unknown to them. Also $38.2 \%$ of the respondents looked for accommodation through friends or family who know the realities of the foreign country. Slightly fewer, $36.6 \%$ of all the young people surveyed focused on learning English, which enabled them to communicate freely with the local society. On the other hand, $21.6 \%$ of the respondents decided to obtain a job abroad through a recruitment agency. In the case of $3.6 \%$ of the respondents, they prepared themselves in further manners as well, e.g. by purchasing appropriate clothing, equipment 
and means for work, obtaining support and guidance from the university or booking a dormitory (tab. 9).

Table 10. Respondent's resources before the trip $(\mathrm{N}=506)$

\begin{tabular}{|l|c|c|}
\hline & $\begin{array}{c}\text { Number of } \\
\text { respondents } \\
\text { (N) }\end{array}$ & $\begin{array}{c}\text { Percentage of } \\
\text { respondents } \\
\text { (\%) }\end{array}$ \\
\hline $\begin{array}{l}\text { Financial means needed to start living in a foreign } \\
\text { country }\end{array}$ & 342 & $67,6 \%$ \\
\hline Knowledge of a foreign country & 291 & $57,5 \%$ \\
\hline $\begin{array}{l}\text { School completion confirmed by diplomas and } \\
\text { certificates enabling employment }\end{array}$ & 130 & $25,7 \%$ \\
\hline Migration experience & 41 & $8,1 \%$ \\
\hline $\begin{array}{l}\text { Close people living abroad (friends, family, } \\
\text { acquaintances) whom you can rely on }\end{array}$ & 3 & $34,2 \%$ \\
\hline Other & 506 & 173 \\
\hline Total & & $0,6 \%$ \\
\hline
\end{tabular}

Source: Own calculations

Apart from proper preparation, equally important are resources that the respondents had before going abroad (tab.10). As declared by $67.6 \%$ of the interviewees, they had sufficient financial resources for the beginning of their life in a foreign country. Slightly more than a half of the respondents $57.5 \%$ - knew the foreign language they were intending to use after arriving in the selected country. In case of $34,2 \%$ of respondents they were able to rely on help and support from close people, family, friends etc. who live abroad. Only $8,1 \%$ of respondents had migration experience they could potentially use. Two individuals did not possess any resources, in addition to one individual admitted that the most important thing he/she had was an open mind for innovation and surprising adversities. 
Table 11. Respondents' relatives working outside Poland (N=797)

\begin{tabular}{|l|c|c|}
\hline & $\begin{array}{c}\text { Number } \\
\text { of respondents } \\
\text { (N) }\end{array}$ & $\begin{array}{c}\text { Percentage } \\
\text { of respondents } \\
\text { (\%) }\end{array}$ \\
\hline Yes, I have a mum & 27 & $3,4 \%$ \\
\hline Yes, I have a dad & 70 & $8,8 \%$ \\
\hline $\begin{array}{l}\text { Yes, my parents work outside Poland } \\
\text { together }\end{array}$ & 45 & $5,6 \%$ \\
\hline Yes, I have a sister or brother & 94 & $11,8 \%$ \\
\hline $\begin{array}{l}\text { Yes, I have a grandparent or both } \\
\text { grandparents abroad }\end{array}$ & 33 & $\mathrm{~s} 4,1 \%$ \\
\hline Yes, I have friends or acquaintances & 499 & $62,6 \%$ \\
\hline No, I have no relatives abroad & 168 & $21,1 \%$ \\
\hline Total & 797 & $100 \%$ \\
\hline
\end{tabular}

Source: Own calculations

As many as $62,6 \%$ of respondents declared that they have friends or acquaintances who work abroad. On the other hand, $8,8 \%$ have a working dad and only $3,4 \%$ have a mum. This may be due to the fact that men are more likely to leave Poland for work than women, who stay in the country to, for example, focus on bringing up their offspring. In the case of $5.6 \%$ of respondents both parents live and work abroad. Barely $4,4 \%$ of respondents have a grandparent or grandparents who earn a living in a foreign country. On the contrary, $21,1 \%$ of respondents do not know or have any relatives living abroad (tab. 11).

The following issue was to determine why the respondents' relatives reached a decision to depart (tab.12). It turns out that most frequently the departure of parents, friends, acquaintances etc. was motivated by the material situation. Emigration allowed them to earn better, higher salaries than in Poland. This opinion is shared by $40.6 \%$ of those interviewed. According to $20.5 \%$ of respondents, the main motive of their relatives was a desire to enrich themselves quickly with the aim of to be able to realise important plans in the country. 
Table 12. Motives of respondents' relatives when they decided to leave Poland $(\mathrm{N}=643)$

\begin{tabular}{|l|c|c|}
\hline & $\begin{array}{c}\text { Number of respondents } \\
\text { (N) }\end{array}$ & $\begin{array}{c}\text { Percentage of } \\
\text { respondents (\%) }\end{array}$ \\
\hline Unemployment & 43 & $6,9 \%$ \\
\hline Underpaid & 261 & $40,6 \%$ \\
\hline $\begin{array}{l}\text { Perspective of working on "junk } \\
\text { contracts" in Poland }\end{array}$ & 27 & $4,2 \%$ \\
\hline $\begin{array}{l}\text { Lack of prospects for professional } \\
\text { development in the country of } \\
\text { origin }\end{array}$ & 94 & $14,6 \%$ \\
\hline $\begin{array}{l}\text { Willingness to meet new places, } \\
\text { people and change the } \\
\text { environment }\end{array}$ & 62 & $9,6 \%$ \\
\hline $\begin{array}{l}\text { Willingness to earn quickly to } \\
\text { realize important plans in the } \\
\text { country }\end{array}$ & 132 & $20,5 \%$ \\
\hline Other & 23 & $3,6 \%$ \\
\hline Total & 643 & $100 \%$ \\
\hline
\end{tabular}

Source: Own calculations

In turn, $14.6 \%$ of those surveyed consider that they were motivated by the prospect of much better professional development. Slightly less, i.e. 9.6\% of respondents declared that the willingness to become familiar with new places and people was the reason for their migration, and only $4.2 \%$ said that their relatives have left Poland since they were forced to work under the socalled junk contracts. However, $3.6 \%$ of respondents mentioned as well such reasons as marriage, relationship with a foreigner, studying abroad or discrimination based on sexual orientation or origin. It is worth noting that most migration of people close to the respondents, but not only, is motivated primarily by the desire to enrich themselves, to acquire a higher income. The desire to develop professionally is also economically motivated - mainly to improve the material status. 
Table 13. Professional plans of respondents $(\mathrm{N}=808)$

\begin{tabular}{|c|c|c|c|c|c|}
\hline & $\begin{array}{c}\text { I want to stay } \\
\text { and work in } \\
\text { Poland after } \\
\text { school/study }\end{array}$ & $\begin{array}{c}\text { I want to } \\
\text { go to } \mathbf{m y} \\
\text { family } \\
\text { abroad }\end{array}$ & $\begin{array}{c}\text { I want to work } \\
\text { outside of } \\
\text { Poland and be } \\
\text { independent }\end{array}$ & $\begin{array}{c}\text { I haven't } \\
\text { thought } \\
\text { about it } \\
\text { yet }\end{array}$ & Total \\
\hline $\begin{array}{c}\text { Number of } \\
\text { percentage } \\
\text { (N) }\end{array}$ & 385 & 34 & 253 & 136 & 808 \\
\hline $\begin{array}{c}\text { Percentage of } \\
\text { respondents } \\
\text { (\%) }\end{array}$ & $47,6 \%$ & $4,3 \%$ & $31,3 \%$ & $16,8 \%$ & $100 \%$ \\
\hline
\end{tabular}

Source: own calculations

Future plans of the surveyed youth are as well important (tab. 13). Approximately half of the surveyed, i.e. $47.6 \%$ of all respondents would like to remain and work in Poland after obtaining appropriate education. In contrast, $31.3 \%$ definitely declare that they do not plan to stay in Poland, but still would like to settle abroad, obtain a job there and become independent. In addition, only $4,5 \%$ of people interviewed would like to emigrate in the future to join their families who are already living abroad. A small part of respondents $(16,8 \%)$ admitted that they haven't thought yet what they are intending to achieve in the future and they do not have an obligation to explicitly state whether they are intending to stay in Poland or leave.

Table 14. Motives for respondents' peers' reluctance to leave Poland $(\mathrm{N}=806)$

\begin{tabular}{|l|c|c|}
\hline & $\begin{array}{c}\text { Number of } \\
\text { respondents (N) }\end{array}$ & $\begin{array}{c}\text { Percentage of } \\
\text { respondents (\%) }\end{array}$ \\
\hline They are afraid to leave & 147 & $18,2 \%$ \\
\hline $\begin{array}{l}\text { They are afraid to leave because of } \\
\text { terrorism or health reasons (pandemic) }\end{array}$ & 45 & $5,6 \%$ \\
\hline $\begin{array}{l}\text { They do not have to leave because they } \\
\text { will have a good job in Poland }\end{array}$ & 119 & $14,8 \%$ \\
\hline $\begin{array}{l}\text { Their parents will help them, so they do } \\
\text { not have to look for help outside Poland }\end{array}$ & 97 & $12 \%$ \\
\hline
\end{tabular}




\begin{tabular}{|l|c|c|}
\hline $\begin{array}{l}\text { They have the right to do so and decide } \\
\text { for themselves what is most important } \\
\text { in life }\end{array}$ & 352 & $43,7 \%$ \\
\hline $\begin{array}{l}\text { Not enough money to travel and settle } \\
\text { abroad }\end{array}$ & 46 & $5,7 \%$ \\
\hline Total & 806 & $100 \%$ \\
\hline
\end{tabular}

Source: Own calculations

Respondents were also questioned about their opinion on the reason for their peers' reluctance to travel abroad. As $43.7 \%$ of respondents admit, young people have the right to stay in Poland, they own the possibility to make a decision for themselves as well as they are acquainted with what is best for them. According to $18.2 \%$ of respondents, fear is the main reason why young people do not decide to travel abroad. Fear of the unknown makes them prefer to remain in their homeland, even if the environment is difficult and hostile towards them, not conducive to their development. On the other hand, $14.8 \%$ of respondents believe that their peers are not obliged to leave the country, as they will acquire a good quality job without much difficulty, which will provide them with an appropriate, or even high living status. Young people are able to rely on assist from their parents, so they do not require to travel abroad to obtain necessary financial resources - such opinion is shared by $12 \%$ of surveyed people. On the contrary, $5.7 \%$ of all respondents consider that they do not have enough money to settle abroad as well as $5.6 \%$ of respondents are convinced that the main source of youth's desire to stay in Poland is the fear of terrorism and their health. The omnipresent pandemic is not conducive to travel abroad, fear for one's own health moreover the health of one's family and relatives does not allow to migrate. Also, numerous information about terrorist attacks fill them with fear and discourage them from leaving Poland (tab. 14).

Which country is most frequently visited by Poles? As many as $79.4 \%$ of those interviewed consider that the most popular country among Poles who make a decision to migrate is a country neighbouring with Poland, i.e. Germany. Equally popular destination is the United Kingdom - such opinion is shared by more than half of the respondents $(67.9 \%)$. In turn, $43.7 \%$ of respondents suppose that Poles most often migrate to the Netherlands. For $32.4 \%$ of respondents, Norway is the country where Polish migrants settle. 
Table 15. Countries of migration of Poles in the opinion of respondents $(\mathrm{N}=812)$

\begin{tabular}{|l|c|c|}
\hline & Number of respondents (N) & Percentage of respondents (\%) \\
\hline Germany & 645 & $79,4 \%$ \\
\hline Ireland & 152 & $18,7 \%$ \\
\hline Great Britain & 551 & $67,9 \%$ \\
\hline Netherlands & 355 & $43,7 \%$ \\
\hline Italy & 37 & $4,6 \%$ \\
\hline Spain & 33 & $4,1 \%$ \\
\hline Denmark & 47 & $5,8 \%$ \\
\hline Norway & 263 & $32,4 \%$ \\
\hline Finland & 42 & $5,2 \%$ \\
\hline Sweden & 110 & $13,5 \%$ \\
\hline USA & 121 & $14,9 \%$ \\
\hline Austria & 5 & $0,6 \%$ \\
\hline Belgium & 2 & $0,2 \%$ \\
\hline Switzerland & 2 & $0,2 \%$ \\
\hline France & 3 & $0,4 \%$ \\
\hline Iceland & 1 & $0,1 \%$ \\
\hline $\begin{array}{l}\text { Asian } \\
\text { countries } \\
\text { (China etc.) }\end{array}$ & 1 & $0,1 \%$ \\
\hline Total & & $100 \%$ \\
\hline
\end{tabular}

Source: Own calculations

The following, $18.7 \%$ of respondents consider that most Poles travel to Ireland, what is more $14.9 \%$ of those surveyed assume that the United States is the most popular choice. Sweden is, in the opinion of $13.5 \%$ of the surveyed youth, the most frequently chosen country. Popular migration destinations are as well Denmark (5.8\%), Finland (5.2\%), Italy (4.6\%) or 
Spain (4.1\%). According to the respondents, such countries as Austria $(0.5 \%)$, France $(0.4 \%)$, Belgium $(0.2 \%)$, Switzerland $(0.2 \%)$, Iceland $(0.1 \%)$ or Asian countries, e.g. China $(0.1 \%)$ are the least popular destinations for Polish migrants and are not as desired as the above-mentioned countries (tab.15).

Research conducted by CBOS in 2019 confirms that mostly Poles travel to Great Britain. Almost half of respondents (43\%) admit that they have recently or currently work in Germany. At that moment equally popular migration countries are the UK $(23 \%)$ and the Netherlands $(15 \%)^{21}$. The results reflect, confirm the guesses of the surveyed youth.

Furthermore, the surveyed youth was interviewed to indicate a country they would like to settle down in, if they had the opportunity. Germany is the country most frequently chosen by the surveyed $-15 \%$ of respondents admitted that they would like to move to this country. In second place is the United States (12.4\%) followed by Norway (11.9\%). The next most popular destination is the United Kingdom (11.4\%). In turn, 5.8\% of respondents prefer Italy. Moreover, $4.9 \%$ of all respondents would like to migrate to the Netherlands or Spain (4.8\%). Equally attractive countries for settlement are Sweden (4.4\%) and Canada (3.2\%). On the other hand $2.5 \%$ would choose Iceland as a destination. Other opinion is held by $2.3 \%$ of the surveyed youth. For this group of respondents France is a country they would like to travel to. Others would hypothetically migrate to Switzerland (2.1\%), others to Austria (1.7\%), and still others to Ireland (1.7\%) or Australia (1.6\%). There is a growing interest in Japan (1.4\%) and Denmark (1.4\%) among respondents. Also features (1.1\%), Finland (1\%) and Belgium $(0.9 \%)$ are the destinations of respondents. Also $0.9 \%$ of respondents would like to travel to any of the Scandinavian countries and still other respondents to Scotland $(0.9 \%)$. Equally keen respondents would emigrate to India $(0.4 \%)$, Portugal $(0.4 \%)$, Greece $(0.4 \%)$, South Korea $(0.4 \%)$. New Zealand $(0.3 \%)$, Russia $(0.3 \%)$, Thailand $(0.3 \%)$, Estonia $(0.3 \%)$, Croatia $(0.3 \%)$, Hungary $(0.3 \%)$, the United Arab Emirates (0.3\%), Wales (0.3\%), are the next countries selected by respondents. The least popular countries are Vietnam $(0.1 \%)$, Turkey $(0.1 \%)$, Malta $(0.1 \%)$, Chile $(0.1 \%)$, Egypt $(0.1 \%)$, Belarus $(0.1 \%)$, Madagascar $(0.1 \%)$, Luxembourg (0.1\%), Ecuador $(0.1 \%)$, Jamaica $(0.1 \%)$, Liechtenstein $(0.1 \%)$, Mexico $(0.1 \%)$ and Colombia (0.1\%). For $0.4 \%$ of the

\footnotetext{
${ }^{21}$ Centrum Badania Opinii Społecznej, Wyjazd Polaków do pracy za granicę, no. 140/2019, https://www.cbos.pl/SPISKOM.POL/2019/K_140_19.PDF, p. 5 [accessed: 10.01.2021].
} 
respondents, it is not the location that matters to them, but the right working conditions. This means that these people are primarily focused on profit as well as enriching themselves. A different attitude is adopted by $0.3 \%$ of those questioned, who would like to lead a travelling lifestyle, not wanting to settle down only in one country, but travelling and sightseeing all the time. Only $0.3 \%$ of all respondents admit they want to stay in Poland and are not planning to change their place of residence in the future. Only $0.4 \%$ of respondents do not know what their migration destination could be however one person prefers English-speaking countries.

The young people surveyed listed almost 50 countries they could hypothetically travel to if they were considering migration. The most frequently mentioned countries are large ones, where there is a possibility of professional and private development. Popular European countries predominate, with Asian countries still accounting for a small percentage of responses. Scandinavian or Western countries are of great interest.

Respondents were further interviewed about the reasons for their hypothetical departure. The most frequent answer among the respondents was earnings $-24.3 \%$ of those questioned shared this opinion. Slightly fewer $19.1 \%$ of the respondents - would come to a decision to depart in order to be able to realise their own plans for life. For $17.7 \%$ of respondents the most important motive for leaving Poland is their great desire and passion to travel and visit foreign countries. Travelling will allow them to visit further and more diverse places in the world as a result they will not only gain knowledge about various cultures but also broaden their horizons. Another important motive for hypothetical travelling, according to the young people surveyed is the possibility of improving one's living standard $-15.9 \%$. I am fed up with life in Poland - such conviction was expressed by $11.5 \%$ of respondents. According to the respondents, an equally important reason to migrate is the dislike for Poland (11.5\%) or the possibility to increase one's social status (3.5\%). Only $0,6 \%$ of respondents admit that they would leave just to be far enough away from their family, loved ones. This shows that only a small percentage of respondents do not take into account such values in their lives as family or friends. On the basis of the obtained results, it is also possible to formulate a hypothesis that not only financial benefits are important for the youth, equally important is realization of their own plans for life, which in their opinion are impossible to achieve in Poland or are difficult (tab. 16). 
Table 16. Hypothetical motives for travelling outside Poland $(\mathrm{N}=800)$

\begin{tabular}{|l|c|c|}
\hline & $\begin{array}{c}\text { Number of } \\
\text { respondents (N) }\end{array}$ & $\begin{array}{c}\text { Percentage of } \\
\text { respondents (\%) }\end{array}$ \\
\hline Earnings & 194 & $24,3 \%$ \\
\hline $\begin{array}{l}\text { Opportunity to realise own plans for life } \\
\text { in a foreign country }\end{array}$ & 153 & $19,1 \%$ \\
\hline Opportunity to increase social status & 28 & $3,5 \%$ \\
\hline Possibility of raising the standard of living & 127 & $15,9 \%$ \\
\hline To be away from family & 5 & $0,6 \%$ \\
\hline I have family or friends abroad & 59 & $7,4 \%$ \\
\hline I like travelling, visiting foreign countries & 142 & $17,7 \%$ \\
\hline I am fed up with life in Poland & 92 & $11,5 \%$ \\
\hline Total & 800 & $100 \%$ \\
\hline
\end{tabular}

Source: Own calculations

Young respondents were also interviewed about the sources of their knowledge on further countries (tab. 17). A significant part of respondents $(69 \%)$ admitted that they obtain important information on countries, their culture or tradition from the Internet. For $16.2 \%$ of the interviewed, parents as well as friends are a treasury of knowledge with reference to other nations. In turn $11.1 \%$ of respondents acquire their knowledge from books or specialist literature. Such mass media as TV $(2.7 \%)$ or press (1\%) are less and less popular among young respondents as well as they prefer quick and accessible solutions like the Internet.

Table 17. Sources of knowledge about other countries and states used by respondents etc. $(\mathrm{N}=809)$

\begin{tabular}{|c|c|c|c|c|c|c|}
\hline & $\begin{array}{c}\text { From } \\
\text { family and } \\
\text { friends }\end{array}$ & $\begin{array}{c}\text { From } \\
\text { internet }\end{array}$ & $\begin{array}{c}\text { From } \\
\text { television }\end{array}$ & $\begin{array}{c}\text { From } \\
\text { press }\end{array}$ & $\begin{array}{c}\text { From books } \\
\text { and specialist } \\
\text { literature }\end{array}$ & Total \\
\hline $\begin{array}{c}\text { Number of } \\
\text { respondents (N) }\end{array}$ & 131 & 558 & 22 & 8 & 90 & 809 \\
\hline $\begin{array}{c}\text { Percentage of } \\
\text { respondents (\%) }\end{array}$ & $16,2 \%$ & $69 \%$ & $2,7 \%$ & $1 \%$ & $11,1 \%$ & $100 \%$ \\
\hline
\end{tabular}

Source: Own calculations 
Deciding to depart is frequently not a simple decision, therefore respondents were interviewed whether they think it is important to consult family and relatives or not. More than half of the respondents (59.4\%) admit that the opinion of family and relatives is important, nevertheless the most important are their own preferences and thoughts, as well as they would be guided by them in case of such an important life change as leaving. On the other hand, $33.2 \%$ of respondents consider that it is worth making the decision to leave based on advice and suggestions from loved ones. Only $7.4 \%$ of the respondents are of a different opinion. They stated that the opinion of others is not significant, they come to a decision about their life on their own, not paying attention to other people. On the basis of the obtained results, it can be concluded that young people mostly value the opinion of their relatives, however at the same time listen to their own self and opt for a kind of individualism. Values such as family and friends are still appreciated by young respondents.

The next question concerned the period of time which, according to the young people surveyed, is the most appropriate for migration (tab.18). Respondents most willingly prefer travelling abroad for a short period of time, for 2-3 months, in order to earn some money for holidays $-24.7 \%$ of the interviewed people were in favour of such a possibility. For $23.9 \%$ leaving is connected with graduation, another school or gaining experience, as a result migration would last a few years, and then they would return to their home country. If they leave, it should be for good - this opinion is shared by $18 \%$ of all respondents. Most often these are people who plan to depart or who have already lived abroad for a considerable period of time. Slightly fewer, $17.9 \%$ of respondents think that they should leave for a few years, which means that they do not wish to leave their homeland permanently. A dissimilar opinion is held by $15.5 \%$ of those interviewed, who consider that their departure should last a year at the most. It can be assumed that these people leave in order to earn enough money and then return to their home country. 
Table 18. Time spent abroad according to respondents $(\mathrm{N}=805)$

\begin{tabular}{|l|c|c|}
\hline & $\begin{array}{c}\text { Number of } \\
\text { respondents (N) }\end{array}$ & $\begin{array}{c}\text { Percentage of } \\
\text { respondents (\%) }\end{array}$ \\
\hline $\begin{array}{l}\text { Short term, to earn money for holidays (2-3 } \\
\text { months) }\end{array}$ & 199 & $24,7 \%$ \\
\hline Short term, up to one year & 125 & $15,5 \%$ \\
\hline $\begin{array}{l}\text { Several years, to gain work experience, } \\
\text { complete studies or other schooling abroad }\end{array}$ & 192 & $23,9 \%$ \\
\hline Several years & 144 & $17,9 \%$ \\
\hline If leaving, staying permanently & 145 & $18 \%$ \\
\hline Total & 805 & $100 \%$ \\
\hline
\end{tabular}

Source: Own calculations

Travelling alone or in a group? According to the respondents a group trip is better. According to $31.4 \%$ of respondents group travel is more attractive and safer $-31.1 \%$ of respondents share this view. On the other hand, $18.3 \%$ of respondents prefer a solo trip, nevertheless one should follow the beaten track and rely on the knowledge and opinion of friends and relatives who are in a foreign country. What is more, $13,5 \%$ of the total number of the respondents prefer travelling alone, for the reason that it allows total freedom. Such travelling is more comfortable, you are able to do what you would like to do, with whom you wish, you are able to focus simply on yourself and your goals. Only $5,7 \%$ of respondents do not have any migration experience and desire to stay in Poland so they do not have an opinion on this issue.

An equally important question concerned the attitude of the surveyed youth towards migrants in Poland (tab. 19). It turns out that $40.4 \%$ of respondents claim that migrants do not bother them, thus they have a neutral attitude to them, and one may assume that it is surprisingly positive. Furthermore, $34.3 \%$ of respondents expressed their approval of migrants. Their estimation is that Poles have been migrating for a long period of time, consequently this cannot be forbidden to other individuals. The subject of migration is a foreign topic for $6.6 \%$ of the respondents, and $11.8 \%$ have no opinion on migration. Only $6.9 \%$ of respondents expressed significant opposition to foreigners coming to Poland. It can be concluded that barely a small 
percentage of the surveyed young people manifest xenophobia or chauvinism and have a positive attitude towards individuals visiting Poland.

Table 19. Respondents' opinions on the presence of migrants in Poland $(\mathrm{N}=807)$

\begin{tabular}{|l|c|c|}
\hline & $\begin{array}{c}\text { Number of } \\
\text { respondents (N) }\end{array}$ & $\begin{array}{c}\text { Percentage of } \\
\text { respondents (\%) }\end{array}$ \\
\hline Migrants do not bother me & 326 & $40,4 \%$ \\
\hline $\begin{array}{l}\text { I fully support migration as Poles have been } \\
\text { migrating for a long time }\end{array}$ & 277 & $34,3 \%$ \\
\hline $\begin{array}{l}\text { I am against foreign citizens coming to } \\
\text { Poland }\end{array}$ & 56 & $6,9 \%$ \\
\hline I am not interested in migrations & 53 & $6,6 \%$ \\
\hline I have no opinion & 95 & $11,8 \%$ \\
\hline Total & 807 & $100 \%$ \\
\hline
\end{tabular}

Source: Own calculations

Travelling alone or with relatives? According to the respondents, the best solution is to migrate together with the family or someone close to you in order not to leave your relatives in Poland $-41,9 \%$ of the respondents opted for this response. Migration together allows to avoid such consequences as longing or breaking the bonds with the loved ones. In turn, for $36.8 \%$ of respondents it is irrelevant whether they depart unaccompanied or with somebody else. Whether they are by yourself or in a group they feel secure and have no objections to travelling alone. On the other hand $12.7 \%$ of the respondents think that it is best to travel on your own, as only in such circumstances a trip could be most beneficial, you are able to focus on yourself and your plans. Travelling alone is as well the right choice according to $8.6 \%$ of the respondents. However, they underline that going alone departure should not last longer than one year. After that, they should return to their homeland (tab. 20). 
Table 20. Ways of travelling in the opinion of respondents $(\mathrm{N}=813)$

\begin{tabular}{|l|c|c|}
\hline & $\begin{array}{c}\text { Number of } \\
\text { respondents (N) }\end{array}$ & $\begin{array}{c}\text { Percentage of } \\
\text { respondents (\%) }\end{array}$ \\
\hline $\begin{array}{l}\text { Individual trip - trip should be short, } \\
\text { max one year }\end{array}$ & 70 & $8,6 \%$ \\
\hline $\begin{array}{l}\text { Individual departure - the trip should } \\
\text { be beneficial for an individual migrant } \\
\text { and not others }\end{array}$ & 103 & $12,7 \%$ \\
\hline $\begin{array}{l}\text { Departure only with family or someone } \\
\text { close (boyfriend, girlfriend, partner) not } \\
\text { to leave relatives in Poland }\end{array}$ & 341 & $41,9 \%$ \\
\hline It does not matter & 299 & $36,8 \%$ \\
\hline Total & 813 & $100 \%$ \\
\hline
\end{tabular}

Source: Own calculations

What consequences may occur along with migration - this was a further question posed to the surveyed youth (tab. 21). More than half of the respondents $(63.3 \%)$ claim that migration might cause deterioration of relations with family and relatives. Moreover, they might as well contribute to relationship breakdown, e.g. marriage, partnership, engagement, etc. - as $53.6 \%$ of respondents believe. Slightly fewer, i.e. $51.7 \%$ of respondents declare that, in their opinion, going abroad is connected with longing for relatives, friends, acquaintances, etc., as well as according to $40.8 \%$ of respondents this longing also concerns Poland and Polishness, i.e. tradition, culture, regionalism, which is missing abroad. The young people surveyed perceive migration as having the most negative impact on interpersonal relations. Deterioration of physical or mental state is a negative result of migration according to $28.8 \%$. Hard, exhausting work, longing, the feeling of alienation may have a significant impact on the health of people who decide to depart. Barely $6.3 \%$ of respondents consider that the main effect is the deterioration of the financial situation. Such a small percentage in favour of this response might be due to the fact that most frequently migration is related to earning money as well as migrants manage to improve their economic status. Only $4.3 \%$ of the total number of respondents do not perceive any negative consequences of migration. 
The authors as well determined to ask the surveyed youth about transnational issues. More than half of the respondents (63\%) stated that yes, nowadays transnationality should be everyone's standard of living. On the other hand, $37 \%$ are of the opposite opinion and deny that it is a significant fact.

Table 21. Consequences of migration according to the respondents $(\mathrm{N}=812)$

\begin{tabular}{|l|c|c|}
\hline & $\begin{array}{c}\text { Number of } \\
\text { respondents (N) }\end{array}$ & $\begin{array}{c}\text { Percentage of } \\
\text { respondents (\%) }\end{array}$ \\
\hline $\begin{array}{l}\text { Deterioration of relationships with family } \\
\text { and relatives, i.e. friends }\end{array}$ & 514 & $63,3 \%$ \\
\hline $\begin{array}{l}\text { Breakdown of relationships e.g. marriage, } \\
\text { partnership, engagement etc. }\end{array}$ & 435 & $53,6 \%$ \\
\hline $\begin{array}{l}\text { Breakdown of relationships e.g. marriage, } \\
\text { partnership, engagement etc. }\end{array}$ & 420 & $51,7 \%$ \\
\hline $\begin{array}{l}\text { Longing for Poland and Polishness i.e. } \\
\text { tradition, culture or regionalism }\end{array}$ & 331 & $40,8 \%$ \\
\hline Deterioration of financial situation & 51 & $6,3 \%$ \\
\hline Deterioration of physical or mental health & 234 & $28,8 \%$ \\
\hline No negative consequences & 35 & $4,3 \%$ \\
\hline Total & 812 & $100 \%$ \\
\hline
\end{tabular}

Source: Own calculations

Does the political situation in Poland favour migration? More than half of the respondents $(57.8 \%)$ say yes. In their opinion, the migration policy in Poland is faulty (e.g. tax abolition), it does not favour society. The opposite view is held by $7.9 \%$ of respondents who believe that the state's political strategy is irrelevant, since people go abroad mainly for work. Slightly fewer $-7.2 \%$ of respondents - are as well convinced that politics has no influence on migration. Everyone has the right to live where and when they desire, as well as increased transnational movements encourage a lot of travel. On the other hand, $14,7 \%$ of respondents admit they have not thought about this issue so far and therefore do not have any opinion on it (tab. 22). 
Table 22. Respondents' answers to the survey question concerning the influence of the political situation in Poland on migration $(\mathrm{N}=809)$

\begin{tabular}{|l|c|c|}
\hline & $\begin{array}{c}\text { Number of } \\
\text { respondents (N) }\end{array}$ & $\begin{array}{c}\text { Percentage of } \\
\text { respondents (\%) }\end{array}$ \\
\hline $\begin{array}{l}\text { Yes, it does, because people feel excluded } \\
\text { and deprived of influence over their own } \\
\text { lives }\end{array}$ & 468 & $57,8 \%$ \\
\hline $\begin{array}{l}\text { Yes, it does, because migration policy in } \\
\text { Poland is flawed, e.g. abolition of tax } \\
\text { abolition }\end{array}$ & 100 & $12,4 \%$ \\
\hline $\begin{array}{l}\text { No, political situation has no impact on } \\
\text { migration, as people nowadays leave mainly } \\
\text { for economic reasons }\end{array}$ & 64 & $7,9 \%$ \\
\hline $\begin{array}{l}\text { It has no impact, we are currently living in } \\
\text { times of increased transnational movement } \\
\text { and everyone can live where and when they } \\
\text { want }\end{array}$ & 58 & $7,2 \%$ \\
\hline I have not thought about it yet & & 119 \\
\hline Total & 809 & $100 \%$ \\
\hline
\end{tabular}

Source: Own calculations

\section{SUMMARY AND CONCLUSIONS FROM THE ANALYSIS OF THE COLLECTED EMPIRICAL MATERIAL}

As Wioletta Danilewicz states, there is no single, fixed motive or opportunity to migrate, since the complexity of contemporary life is determined by "the combination of circumstances that make people decide to change their environment permanently or temporarily. Making the decision to emigrate also requires - in most cases - a strong motivation" and the fulfilment of the once famous American Dream, i.e. the opportunity to fulfil one's dreams or to live a more dignified life. As showed by her, referring to the works of Stephen Castles and Marc Miller, that currently the migration patterns might be shaped by the following migration patterns: globalisation of migration, its 
acceleration, diversification and feminisation ${ }^{22}$. The author further distinguishes the following migration strategies:

1. Fluid migration and transmigrations (weak connection of some migrants with Poland). They frequently depart with their families, work there as well as educate their children. In case of failure they do not return to their country of origin, just search for a further place.

2. Sectoral strategy results from the work performed by migrants and depending on the country of settlement it is different (e.g. in the UK Poles are located in construction, services or industry, while in the Netherlands the agricultural and horticultural sector is dominant).

3 . The strategy of delayed spatial dispersion refers to the so-called 'spillover' of migrant flows of Poles in the UK from the metropolis to neighbouring and then - peripheral areas. In other countries (such as Norway, Spain, Germany, the Netherlands) this phenomenon occurs less frequently due to established migration chains, ${ }^{23}$.

4. The strategy of latent professional depreciation is to work in sectors where there is a demand for unskilled workers, this involves a depreciation of migrants' qualifications (brain waste). It involves the strategy of "intentional unpredictability", i.e. "a sense of short-livedness in doing a certain job seeking better opportunities (here in the sphere of work) and the strategy of the hoarder who does not require changes to increase his/her prestige but seeks consumption on return to the sending country. However, it should be clearly emphasised that the possibility of employment according to a high level of qualification is increasingly used by migrants" 24 .

5. The strategy of "greed for work" refers, as the name suggests, to the desire to earn money quickly, mainly in seasonal, short-term jobs.

6. The strategy of leaving the shadow economy refers to the possibility of working legally.

7. The "non-family" strategy is mainly driven by single people without commitments. These people predominate while people in stable relationships only represent about $30 \%$ of migrants. The "post-accession phenomenon of multi-unit households" formed by unrelated people was discovered ${ }^{25}$.

8. Family strategy - mainly long-term migration and settlement in order to reunite families and build a life in the new country.

\footnotetext{
${ }^{22}$ W. DANILEWICZ, Wybrane cechy i strategie poakcesyjnych migracji z polski, "Warmińsko-Mazurski Kwartalnik Naukowy, Nauki Społeczne” 2012, no. 1, p. 34.

${ }^{23}$ Ibidem, p. 35.

${ }^{24}$ Ibidem.

${ }^{25}$ Ibidem.
} 
9. Return migration - refers to individuals (re-emigrants) who return to Poland, however after a certain period of time travel back abroad, furthermore those migrants who remain permanently in their country of origin. There is a growing proportion of individuals with dual citizenship among reemigrants as a 'gateway' to possible trip abroad. These individuals are usually between 20 and 39 years old ${ }^{26}$.

Empirical research carried out among students has provided many interesting conclusions regarding migration strategies and migration factors of Poles in the opinion of the respondents.

1. It turns out that the main reason for migration is the desire to earn money. According to the respondents, who have migration experience $(40,6 \%)$ as well as to those who are considering migration $(24,3 \%)$, the salary in Poland is very low that it is necessary to travel abroad to really get rich.

2. Based on the obtained results, it might also be concluded that the surveyed young people somehow equate migration with getting rich as well as earning money. $3 / 4$ of the respondents $(74.8 \%)$ would leave Poland due to too low earnings as well as $41.1 \%$ of the respondents would leave their homeland for a certain period of time in order to earn enough money to fulfil their plans upon returning to their homeland. As understood by the respondents, these plans are primarily of a financial, economic and material nature. The willingness to travel in order to become rich may be a manifestation of materialism and consumerism of youth, who mainly focus on the value of money and accumulation of numerous material goods. Travelling in order to broaden one's horizons, get to know new places, cultures is not significantly important for the respondents in the case of migration. This opinion is shared by a small percentage of respondents.

3. According to respondents migration is rather short term. Merely 5,3\% of the surveyed migrants left Poland permanently and 18\% of respondents hypothetically consider such a possibility. Respondents prefer to leave for a while and after that return to Poland or move again to another foreign country. It may be assumed that such a state of affairs is also related to generating income - leaving abroad to earn money and then returning to the home country to fulfill certain plans. The type of hamster and bush migrant is appropriate in this case. There are no references and characteristics of a classical migrant among the respondents.

4. Among the respondents, the desire to remain in Poland, to study here, and afterward to obtain a job, develop their professional and private life pre-

\footnotetext{
${ }^{26}$ Ibidem, p. 47.
} 
vails $-47.6 \%$ of all respondents. In respondents' opinion young people do not desire to leave Poland for the reason that they are fully entitled to do so, they make a decision about themselves, their future and they are familiar with what is best for them. This opinion is shared by $43.7 \%$ of respondents. This way of thinking by young people underlines their need for independence, right to free choice as well as strong individualism.

5. The research confirmed the importance of the Internet in providing and gaining information. Only $1 \%$ of the respondents get their knowledge from press and $2,7 \%$ from television. The Internet is mainly a source of knowledge about foreign countries, their culture etc. (69\%).

6 . When leaving the country, respondents value the opinion of their family - this confirms the validity of the friction factors of migration as well as the NELM theory (New Economics of Labor Migration-NELM theory. Thus, NELM draws on sociology and anthropology to take into account the characteristics of the family, which are crucial for acquiring the means to migrate, emotional and psychological support (e.g. during failures). Therefore, this theory is also called the (Household theory of migration) ${ }^{27}$. While making important life decisions, such as migration, the surveyed group of young people values the opinions of close relatives, while maintaining individualism - the final decision is based on their own convictions and thoughts (59.4\%). The surveyed young people can rely on help from loved ones in the case of such important issues. Only a minority of respondents $(7.4 \%)$ reject any advice from third parties, family, relatives and rely solely on their own opinion. On the other hand, in the case of the surveyed group which has had the experience of migration, they made the decision only on the basis of their own convictions and views $-26.1 \%$ of the respondents - or on the basis of calculating the cost of living in Poland and abroad $-24.4 \%$ of the respondents. On this basis, it can be concluded that life outside the borders of Poland is cheaper, more profitable and the living conditions of the individual much better.

7. The respondents were also interviewed about their own migration experiences - the respondents most often travelled abroad alone $(42.3 \%)$ or with friends or a group of friends $(40 \%)$. Thus, they opted for individualisation, other than used migration chains or migration networks. - Respondents were much more likely to decide to travel abroad together with their family or relatives, as they would not wish to leave them in Poland $-41.9 \%$ of those interviewed expressed this opinion. This may be related to the negative

\footnotetext{
${ }^{27}$ P. STALKER, The No-nonsense Guide to Internetional Migration, London: Versa 2001, p. 22.
} 
consequences of migration. Fear of relationship or marriage breakdown or longing for family or relatives may cause them to prefer travelling together with family or relatives.

8. Respondents appeared to be open to the world, change and innovation, as most of them do not display xenophobic or chauvinistic attitudes towards foreigners coming to Poland. Respondents are neutral towards migrants $(40.4 \%)$ or positive and support migration (34.3\%). More than half of the respondents $(63 \%)$ state that transnationalism should be everyone's standard of living. Also the development of transnationalism according to respondents is influenced by the political situation in Poland, which is not favourable for the society. According to $57.8 \%$ of respondents this state of affairs makes people feel excluded and deprived of influence on their own lives.

9. The most popular countries chosen by respondents are Germany (15\%), USA $(12,4 \%)$ and Norway $(11,9 \%)$. As the respondents themselves admit, the choice of these countries is influenced by the possibility of high salaries $(24,3 \%)$, the possibility to realize one's own plans for life, $(19,1 \%)$ and improvement of living conditions $(15,9 \%)$.

\section{BIBLIOGRAPHY}

DANILEWICZ W., Wybrane cechy i strategie poakcesyjnych migracji z polski, "Warmińsko-Mazurski Kwartalnik Naukowy, Nauki Społeczne” 2012, no. 1, pp. 33-49.

DrinKWATER S., EAdE J., GARAPICH M.P., Polscy migranci w Londynie - klasa społeczna i etniczność. Center for Research on Nationalism, Ethnicity and Multiculturalism, University of Surrey. CRONEM 2006, https://www.surrey.ac.uk/cronem/files/RAPORT-finalny.pdf [accessed: 01.01.2016].

ELLIS F., Rural livelihoods and diversity in developing countries, Oxford: Oxford University Press 2000.

Fudge J., Global Care Chains: Transnational Migrant Care Workers, http://www.ialsnet.org/ meetings/labour/papers/FudgeCanada.pdf [accessed: 12.12.2011].

GACEK M., Strategie migracyjne Polaków po 2004 roku. Przypadek Szkocji, "Pogranicze. Polish Borderlands Studies" 1(2013), no. 1, pp. 106-116.

KLIMEK Ł., Polscy migranci mieszkający w Irlandii ich strategie akulturacyjne i stosunek wobec integracji, "Studia Migracyjne - Przegląd Polonijny” 38(2012), no. 3, pp. 27-49.

KNIEJSKA P., Between virtual intimacy and the transfer of family members to the workplace. Strategies of migrant care workers to deal with the temporary separation from their families in Poland, "Studia Migracyjne - Przegląd Polonijny" 41(2015), no. 3(157), pp. 123-138.

KozaK S., Patologia eurosieroctwa w Polsce. Skutki migracji zarobkowej dla dzieci i ich rodzin, Warszawa: Wydawnictwo Difin 2010.

KozIElska J., Poakcesyjne migracje zarobkowe. Kontekst teoretyczno-empiryczny. Wsparcie społeczne, Poznań: Wydawnictwo Naukowe Uniwersytetu Adama Mickiewicza 2014. 
LEE E., A Theory of migration, "Demography" 1966, vol. 3, pp. 47-57.

OKÓLSKi M., GRABOwSKA-LUSiŃSKA I., Najnowsza emigracja z Polski - raport OBM, "Biuletyn Migracyjny" 2008, no. 16, pp. 1, 7-8.

PustuŁKa P., Polish Mothers on the Move: Transnationality and Discourses of Gender, Care, and Co-residentiality Requirement in the Narratives of Polish Women Raising Children in the West, "Studia Sociologica" 4(2012), vol. 2, pp. 162-175.

Richmond A., Immigration and Structural Change: The Canadian Experience 1992, 1971-1986, "International Migration Review" 1992, vol. 26, no. 4, pp. 1200-1221.

Stalker P., The No-nonsense Guide to Internetional Migration, London: Versa 2001.

White A., Polish circular migration and marginality: a livelihood strategy approach, "Studia Migracyjne - Przegląd Polonijny" 42(2016), no. 1(159), pp. 151-164.

\title{
MIGRATION STRATEGIES \\ AND MIGRATION EXPERIENCES OF STUDENTS \\ - BASED ON OWN RESEARCH IN 2020
}

\section{Summary}

In the respect of migration, the movement of people in order to achieve their intended goals (material, emotional, academic, etc.), it remains interesting from a research perspective to study the strategies of migrants as participants in migration to approach their lives as well as shaping life based on travelling abroad. The authors as well base their article on the research experience of other authors who analysed similar or equal aspects of migration of Poles after the enlargement of the European Union structures on $1^{\text {st }}$ May 2004. However, due to the limitations of travelling and the impossibility of carrying out field research, we, as authors, determined to interview the academic youth with reference to their opinions on the mentioned issue. After all, young people assume certain strategies for realizing their own plans for life, which might be related to migration experiences or intentions in this area. In this article, the authors will attempt to explain the matter: what are the preferences and opinions of the respondents (students of Kraków's universities) concerning travelling abroad? We will as well make an effort to define the term of migration strategy from the analytical point of view and we will also try to show the respondents' strategies in connection with their possible migration experiences or migration intentions.

Keywords: migration strategies; life situation; migrations of Poles

\author{
STRATEGIE MIGRACYJNE \\ I DOŚWIADCZENIA MIGRACJE STUDENTÓW \\ - NA PODSTAWIE BADAŃ WŁASNYCH W 2020 R.
}

\section{Streszczenie}

$\mathrm{W}$ podejmowaniu kwestii migracji, będących przemieszczaniem się ludzi w celu realizacji zamierzonych przez siebie celów (materialne, emocjonalne, naukowe itp.), interesujące z punktu widzenia badawczego pozostaje poznanie strategii podejścia migrantów jako uczestników migra- 
cji do swojego życia i kształtowanie go na podstawie wyjazdów lub wyjazdu za granicę. Autorzy artykuł opierają na doświadczeniach badawczych innych autorów, którzy analizowali podobne lub te same aspekty migracji Polaków po rozszerzeniu struktur Unii Europejskiej 1 maja $2004 \mathrm{r}$. Jednakże w związku z ograniczeniami odbywania podróży i niemożnością realizacji badań terenowych, postanowiliśmy zapytać młodzież akademicką o ich opinię w poruszanej problematyce wszak ludzie młodzi zakładają pewne strategie realizacji własnych planów na życie, co wiązać się może z doświadczeniami migracyjnymi lub zamiarami w tym obszarze. Staraliśmy się odpowiedzieć na pytanie: jakie są preferencje i opinie badanych (studentów krakowskich uczelni) w zakresie wyjazdów zagranicznych? Podjęliśmy także próbę określenia terminu strategii migracyjnej z analitycznego punktu widzenia, a także wykazania strategii respondentów w związku $\mathrm{z}$ ich ewentualnymi doświadczeniami migracyjnymi lub migracyjnymi zamiarami.

Słowa kluczowe: strategie migracyjne; sytuacja życiowa; migracje Polaków 